\title{
Methodology of Assessment of the Control Work Efficiency of the Tax Authority
}

\author{
N.V. Chaikovskaya
}

\author{
D.V. Chaikovsky
}

\section{I.V. Terentieva}

Murom Institute (the branch) of the Vladimir State University Russia, 602264, Murom, Vladimir Region, Orlovskaya St., 23

\author{
Doi:10.5901/mjss.2015.v6n6s3p127
}

\begin{abstract}
The paper considers a methodology of assessment of the control work efficiency of tax authorities including a wide range of quantitative and quality indicators covering various aspects of the tax authority activity of. The main units of the offered methodology are the analysis of dynamics, the structure and a plan realization of tax revenues in the budgetary system of the Russian Federation in a section of taxes and the main types of the economic activity; the analysis of dynamics and the structure of arrears on taxes and levies in the budgetary system of the Russian Federation in a section of taxes and the main types of the economic activity; the analysis of control and test activity of the tax authority. The main forms of the statistical reporting of the tax authority are the source for conducting the analysis. The methodology allows providing complexity of the analysis, establishing the reasons of inefficiency of the tax authority's work and developing the system of actions for their elimination. It is directly intended for purposes of the practical application in the analysis of the control and test work of the tax authority of any region.
\end{abstract}

Keywords: control work efficiency, tax authorities, control and test activity, productivity of control actions, tax control.

\section{Introduction}

Now a problem of assessment of the control work efficiency of tax authorities is very actual because the high-quality and productive work of tax inspections causes the timeliness and completeness performance of budget settings on profitable sources at all levels of power. It is very significant in modern conditions of deficiency of financial resources which are necessary for implementation of account obligations of the state and local governments. In this regard existence of a methodology allowing estimating comprehensively and qualitatively the activity of the tax inspection, revealing the problems in the control and test activity and the reasons of their emergence, could promote the development and realization of effective measures on the increaseв performance of tax authorities.

\section{Literature Review}

Now there is no unified approach to the solution of questions concerning how and by what criteria to estimate the work of tax authorities. A significant amount of methodologies which are various on the information base and purposes is developed. For example, methodologies of the Federal Tax Service of Russia: a methodology of assessment of the control work efficiency of tax authorities on the basis of comparison of indicators; an assessment methodology developed for application by higher inspectorates making the vertical (departmental) control; a methodology of assessment of the control work efficiency of the FNS of Russia on subjects of the Federation (see the official site of the FNS of Russia; The order of the Ministry of Taxes and Tax Collection of the Russian Federation from 01.09.2003 № BG-3-06/481 \& Official site of the Federal tax authority of the Russian Federation, // http://www.nalog.ru). The author's methodologies offer to analyze the control and test activity of the tax authority on the basis of a unified integrated indicator: a coefficient of taxes charge (Shcherbinin A.T., 2007), a coefficient of economic efficiency of the tax administration (Krylov D.V. 2000), a reserve of a tax potential (Kartashova G.N., 2003).

Possessing significant advantages these methodologies, unfortunately, do not allow to investigate the results of the tax authority work in a complex in this connection no of them was not widely adopted. Methodologies of the FNS of Russia include a wide set of indicators, however, they do not even cover all aspects of the control work of the tax authority which must be investigated for the effective management by it. 
In this regard the aim of the research is formation of a complex methodology of assessment of control and test activity efficiency of tax authorities and its approbation on the example of the Interdistrict Inspection of the Federal Tax Service of Russia № 4 for the Vladimir region (Official site of the Federal tax authority of the Russian Federation. // http://www.nalog.ru).

When developing a methodology, both native and foreign scientists' research results in the field of formation of the system of indicators on efficiency and productivity of the activity of tax authorities (Morozov M.S., 2007; Zolochevskaya E.Yu., 2011; Meshkova D.A., 2011 \& Semenova O.Yu. \& Kiselyov N.V., 2012;) and also in the field of assessment of the tax administration's quality (Smirnova E.E., 2008; Efremova T.A., 2014; Kangave J., 2005 \& Stiglingh M., 2014) were used.

\section{Methodology}

The comprehensive analysis of the tax authority's activity for the development of measures on prevention of tax offenses must be conducted on the following directions:

- the analysis of dynamics, the structure and a plan realization of tax revenues in the budgetary system of the Russian Federation in a section of taxes and the main types of the economic activity;

- the analysis of dynamics and the structure of arrears on taxes and levies in the budgetary system of the Russian Federation in a section of taxes and the main types of the economic activity;

- the analysis of control and test activity of the tax authority.

The main methods when conducting the analysis are: the horizontal - a comparison of each position of accounts with the previous period, the vertical - a definition of the structure of final indicators with identification of the influence of each position of accounts on the result in general, the method of relative indicators, the factorial analysis of the influence of separate factors on a productive indicator with the use of the determined or stochastic methods of the research.

\section{Results}

The analysis of dynamics, the structure and a plan realization of receipts to the budgetary system of the Russian Federation in a section of taxes is made on the basis of accounts of the tax authority "On taxes flow and charge, collections and other obligatory payments in the budgetary system of the Russian Federation" (the form № 1-NM). Thus, for obviousness of the conducting the analysis it is expedient to develop a new form of internal tax accounts, a way of data classification in which it will promote faster and effective research. Besides, with the use of this form, it is will possible not only to show dynamics of indicators, but also to establish reasons of their changes.

Figure 1 presents the algorithm of conducting the analysis. The analysis of dynamics, the structure and plan realization of tax revenues to the budgetary system of the Russian Federation in a section of the main types of the economic activity is conducted in the same way. The source of information for conducting this type of the analysis is the inspectorate accounts "On tax payments flow to the budgetary system of the Russian Federation on the main types of the economic activity" (form № 1-NOM).

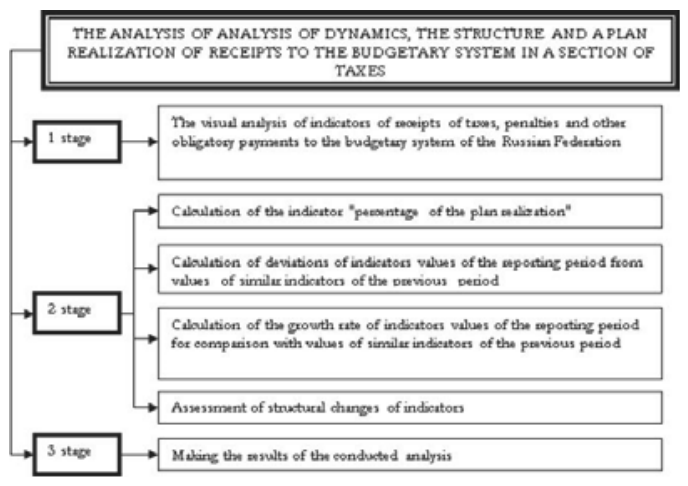

Figure 1 - The algorithm of conducting the analysis of tax revenues to the budgetary system of the Russian Federation in a section of taxes. 
The analysis of dynamics and the structure of arrears on taxes and levies to the budgetary system in a section of taxes and the main types of the economic activity is conducted on the basis of accounts "On arrears on taxes and levies, fines and tax sanctions to the budgetary system of the Russian Federation" (the form №4) and accounts " On arrears on taxes and levies, fines and tax sanctions to the budgetary system of the Russian Federation on the main types of the economic activity" (the form №4 -NOM). Fig. 2 presents the algorithm of conducting the analysis.

The analysis of tax revenues and also arrears on taxes and levies on the above-mentioned algorithms is conducted on the example of the Interdistrict Inspection of the Federal Tax Service of Russia № 4 for the Vladimir region (Chaykovskaya N.V. \& Smirnova M.V., 2015).

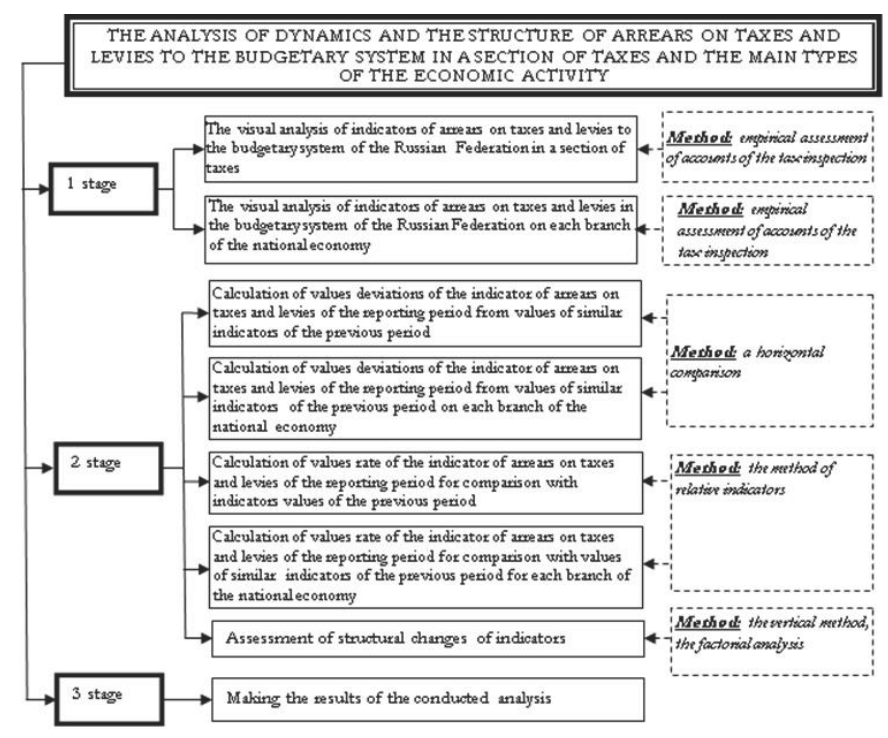

Figure 2 - The algorithm of conducting the analysis of arrears on taxes and levies to the budgetary system of the Russian Federation.

The analysis of the control and test activity of the tax authority is conducted on the basis of the inspectorate accounts "On the results of the control work of tax authorities" (the form 2-NK). Figure 3 presents schematically a methodology of the analysis of the control and test activity of the tax authority.

Each block of methodologies, which the fig. 3, presents consists of several stages. So, the first block "General Assessment of the control and test activity of the tax authority" includes the following stages:

1. Visual assessment of indicators of the inspection control and test activity.

2. Calculation of deviations and the growth rate of a number of tax audits in accounts year in comparison with the previous period.

3. Calculation of deviations and the growth rate of a number of tax audits which have revealed violations of the tax law in accounts year in comparison with the previous period.

4. Calculation of deviations and the growth rate of additional added payments in accounts year in comparison with the previous period.

5. Summing-up of the results of the conducted analysis. 


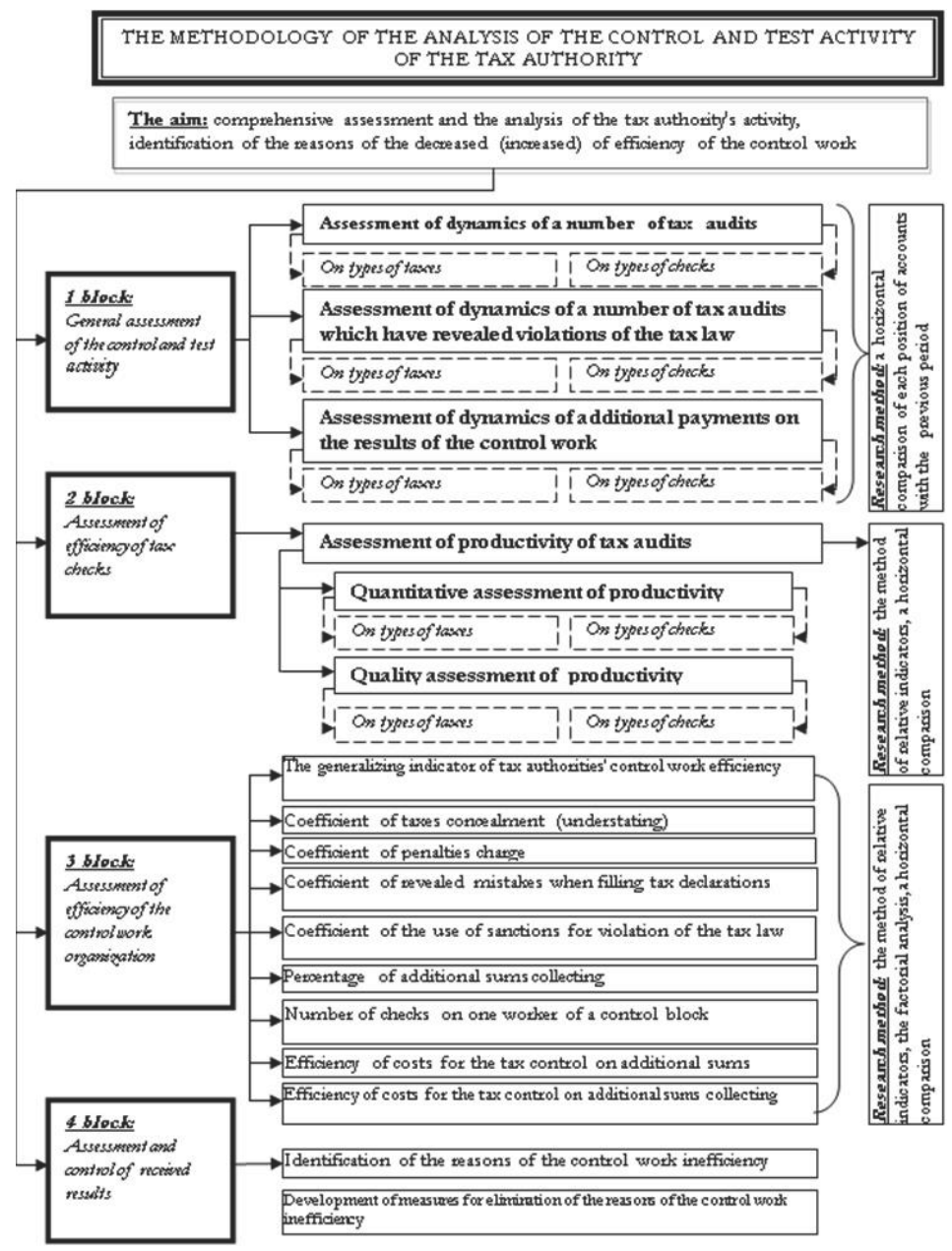

Figure 3 - The methodology of the analysis of the control and test activity of the tax authority (Chaykovskaya N. V., 2011).

The general assessment of the control and test activity is conducted on the example of the Interdistrict Inspection of the Federal Tax Service of Russia № 4 for the Vladimir region (Chaykovskaya N.V. \& Smirnova M.V., 2015).

The second block of a technique includes the calculation of two indicators of control actions productivity:

1. The quantitative index of productivity is calculated by comparison of total number of the conducted tax audits with the checks which have revealed violations of the tax law:

$$
\Pi_{\text {кол }}^{\text {рез }}=\frac{K_{\text {нар }}}{K_{\text {всего }}}
$$

where $\Pi_{\text {кол }}^{\text {рез }}$ is a quantitative index of productivity,

$K_{\text {нар }}$ - is a number of the tax audits which have revealed violations of the tax law;

$K_{8 c e r o}$ - is a number of the conducted tax audits.

The indicator is calculated in a section of types of tax audits and in a section of types of taxes on which such inspections are made. Thus, the productivity of cameral checks, as a rule, is low (3-7\%) because this type of a check is used by all taxpayers. A value of an indicator on exit checks, at the competent system of control actions planning must be 
$100 \%$.

2. The quality indicator of the productivity is calculated by comparison of the volume of the additional payments to a number of tax audits which have revealed violations of the tax law:

$$
\Pi_{\text {кач }}^{\text {рез }}=\frac{\text { Д }}{K_{\text {нар }}}
$$

where $\Pi_{\kappa a ч}^{\text {pes }}$ - is a quality indicator of the productivity;

$\boldsymbol{Z}$ - is additional payments by results of checks;

$K_{\text {нар }}$ - is a number of tax audits which have revealed violations of the tax law.

This indicator allows calculating a size of additional accruals on average falling on one productive tax audit. The quality indicator of the productivity is calculated in a section of tax audits types and in a section of tax types.

Also during the assessment of productivity it is necessary to calculate absolute and relative deviations of indicators. The analysis of dynamics will allow revealing a tendency of the control and test activity of the tax authority that is necessary when developing measures for its improvement.

The third block of a methodology is the assessment of efficiency of the tax authority's control work organization. For this purpose it is necessary to calculate a number of indicators from different sides characterizing the control work of the tax authority.

Such indicators as the generalizing indicator of efficiency of the control work of tax authority, the coefficient of taxes concealment, the coefficient of fines charge, the coefficient of mistakes identification when filling tax declarations and the coefficient of sanctions application for violation of the tax law characterize the activity of the tax authority from the point of view of additional payments. The methodology of calculation of these and some other indicators is given in (Zolochevskaya E.Yu., 2011; Semenova O.Yu., Kiselyov N. V., 2012 \& Efremova T.A., 2014).

However, when making assessment of the results of the control work of the tax authority it is necessary to consider that the quantity of additional taxes, fines, penalties often disperses from that sum which will subsequently come from taxpayers to the budget and off-budget funds. Additional payments receipt on the results of all tax audits (exit and cameral), as a rule, are about 40-50\% (Morozov M.S., 2007). Thus, the indicator of the volume of enforced payments on the results of the control work in accounts of the tax inspection "On the results of the control work of the tax authorities" in the form № 2-NK is absent that is its essential disadvantage.

The indicator characterizing a ratio of the quantity of additional taxes, fines, penalties and the volume of enforced payments is a percentage of penalty of additional sums.

The need of calculation of this indicator is caused by that situations when in the course of exit control by employees of tax authorities the greatest possible additional payments charge on revealed violations sometimes regardless of a possibility of the subsequent proof made at judicial review of the arisen disagreements between a taxpayer and the tax authority are frequent. It is connected with that that the result of the control block work of territorial tax authorities is a value of a quantitative index of additional means while the low indicators of the subsequent penalty belong to the results of the legal department and the department of settlement of arrears and bankruptcy procedures ensuring. At the same time the inadequate overestimate of sums of additional payments is also important. Such approach of control bodies is irrational and demands the improvement. Partly by the use of the existing productivity assessment indicators in their set for all divisions of the inspection at the same time, but not separately, because productive, but not rational work of the control block will lead to goalless work of the block of penalty. But at through assessment of the activity of all inspection it is possible to point out a primary source which work has led to such results (Chaikovskaya, 2015; Chaikovskaya \& Smirnova, 2015 \& Shherbinin, 2007).

If along with it to consider the indicator of a number of checks on one employee of tax authorities correlating a number of checks to a number of staff of the tax authority, it is possible to analyze a load of officials of tax authorities. Thus, exit tax audits and conditional cameral tax audits are among the carried-out inspections. This concept is entered into calculation on order to consider labor costs on carrying out forms of the tax control. On average 1 cameral check demands 1 working hour of one checking person. While the implementation of one exit check on average demands 10 working days of 2 checking persons. The product gives 160 man-hours for carrying out one exit check. We will take labor costs of carrying out exit check for the conditional cameral tax audit. In this case it is necessary to correlate a number of made cameral events to the labor input of carrying out conditional check, having divided them into 160 (Morozov M.S., 2007).

For assessment of macroefficiency of the control work of the tax authority it is necessary to calculate an indicator of efficiency of costs of the tax control. Similar to a productivity indicator, this coefficient is calculated in quantitative and 
high-quality expression.

The quantitative index of macroefficiency of the control work of the tax authority is efficiency of costs for the tax control on additional charges. This indicator represents a ratio of volume of in addition added payments to expenses which were necessary for tax authority for implementation of the activity.

Quality indicator of macroefficiency of examination of tax authority is efficiency of costs of tax control on collecting additional accruals. This indicator represents a ratio of the volume of enforced payments to expenses which were necessary for the tax authority for implementation of the activity.

Similar to previous blocks of a methodology it is necessary to conduct the analysis of dynamics of these indicators that will allow estimating in more detail efficiency of the organization of the control work of the tax authority.

Let's calculate these indicators for assessment of efficiency of the organization of the control work in the Interdistrict Inspection of the Federal Tax Service of Russia № 4 for the Vladimir region (Table 1).

Table 1 - The analysis of efficiency of the control work organization of the Interdistrict Inspection of the Federal Tax Service of Russia № 4 for the Vladimir region for 2012-2014.

\begin{tabular}{|c|c|c|c|c|c|c|c|}
\hline \multirow{3}{*}{ Indicator's name } & \multirow{3}{*}{$2012 \mathrm{y}}$. & \multirow{3}{*}{$2013 \mathrm{y}}$. & \multirow{3}{*}{$2014 \mathrm{y}}$. & \multicolumn{2}{|c|}{ Deviation } & \multicolumn{2}{|c|}{ Growth rate, \% } \\
\hline & & & & $2013 /$ & 20141 & $2013 /$ & $2014 /$ \\
\hline & & & & 2012 & 2013 & 2012 & 2013 \\
\hline The ge & 0,09 & 0,12 & 0,17 & 0,03 & 0,05 & 33 & 142 \\
\hline Coefficient of concealment of taxes & 0,06 & 0,07 & 0,11 & 0,01 & 0,04 & 117 & 157 \\
\hline Coefficient of penalties charge & 0,0001 & 0,0005 & 0,0002 & 0,0004 & $-0,0003$ & 500 & 40 \\
\hline Coefficient of revealed mistakes when filling tax declarations & 0,001 & 0,006 & 0,007 & 0,005 & 0,001 & 600 & 117 \\
\hline Coefficient of the use of sanctions for violation of the tax law & 0,14 & 0,09 & 0,10 & $-0,05$ & 0,01 & 64 & 111 \\
\hline Percentag & 29,2 & 27,5 & 22,6 & $-1,7$ & $-4,9$ & 94 & 82 \\
\hline Numbe & 7 & 7 & 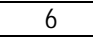 & 0 & -1 & 100 & 86 \\
\hline Efficien & 2,77 & 3,24 & 3,76 & 0,47 & 0,52 & 117 & 116 \\
\hline Efficiency of costs for the tax control o & 0,81 & 0,89 & 0,85 & 0,08 & $-0,04$ & 110 & 96 \\
\hline
\end{tabular}

Thus, on the basis of calculations made in the table 1 it is possible to make the following conclusions. So, the generalizing indicator of efficiency of the control work of the tax authority in 2012 was 0,09. It means that each ruble of accrued according to declarations taxes, fines and penalties and additional as a result of the control work demands 9 kopecks. In 2013-2014 a value of the generalizing indicator of efficiency of the control work has increased respectively by $33 \%$ and $42 \%$. The increased indicator is caused by the increased volume of additional sums on taxes, fines and penalties at simultaneous decrease of sums of accrued taxes according to the submitted declarations of taxpayers.

Similar dynamics is observed concerning the coefficient of taxes concealment. So, in 2012 each ruble of taxes accrued according to taxes declarations demands 6 kopecks of taxes which are additional by the results of the exit check. In 2013-2014 a value of the indicator has increased respectively by $17 \%$ and $57 \%$. The growth of the indicator is caused by the increased volume of additional sums of taxes by the results of control actions (especially in 2014 that testifies about the increased quantity of tax offenses) at simultaneous decrease in sums of accrued taxes according to the submitted declarations of taxpayers.

A value of the fine charge coefficient in 2012 was 0,0001 . It means that in 2012 one ruble of taxes accrued according to declarations demands 0,01 kopecks of additional fines. In 2013 a value of the indicator has increased that testifies to the increased quantity of tax offenses of taxes connected with a untimely payment, collecting and other obligatory payments and submission of tax declarations. In 2014 a value of the indicator has decreased that testifies to the decreased quantity of offenses which were mentioned above.

The coefficient of the revealed mistakes when filling tax declarations in 2012 was 0,001 . It means that during this period each ruble of the taxes accrued according to declarations demands 0,1 kopeck of taxes by the results of cameral check. In 2013-2014 a value of the indicator has increased to 0,006 and 0,007 respectively that testifies to the increased number of tax declarations of the requirements of the Tax code of the Russian Federation made with violations.

The coefficient of application of tax sanctions in 2012 was 0,14 . It means that each ruble of the additionally accrued penalties demands 14 kopecks of additional taxes. In 2013 a value of the indicator has decreased to 0,09 that is connected with a reduction of tax sanctions in the form of penalties at simultaneous increased volume of additional taxes. In 2014 a value of the indicator has slightly increased that is caused by the growth of penalties by the results of checks.

The percentage of penalty of additional sums in 2012 was $29,2 \%$, that means that in this period to the budgetary of 
the Russian Federation system came less than a third of additional payments. In 2013 a value of the indicator has decreased to $27,5 \%$, and in 2014 - to $22,6 \%$. Such low level of the indicator in the analyzed period can be explained by the inadequate overestimate by control bodies of sums of additional payments regardless of a possibility of their real penalty.

Estimating the labor input of the work of employees of the control block of the tax authority we will note that in 2012 and 2013 one tax inspector demands 7 tax audits. In 2014 their quantity has decreased to 6 that is connected with a reduction of a number of taxpayers.

A value of the coefficient of costs of the tax control on additional sums grows in the analyzed period that testifies to the increased efficiency of the control and test activity of the tax authority. So, in 2012 one ruble spent for the activity of the tax authority demanded 2,77 rubles, in $2013-3,24$ rubles, and in $2014-3,76$ rubles of tax payments of additional payments.

A value of the indicator of efficiency of costs of the tax control on penalty of additional sums is lower than the previous indicator and is not higher the one. Besides, dinamics of this indicator in 2014 is negative. So, if in 2013 one ruble spent for the activity of the tax authority demamnded 89 kopecks, in 2014 - 85 kopecks.

The final block of a methodology of the analysis of the control and test activity is making its results, identification of the reasons of inefficiency of the work and the development of actions for their elimination.

\section{Conclusion}

Thus, the offered technique allows providing complexity of the analysis of the control and test work, revealing the main disadvantages of the activity of the tax inspection. This methodology differs from other known methodologies by the structure and the maintenance of the main directions of analytical researches. It is directly intended for the purposes of practical application in the analysis of the control and test work of the tax authority of any region and gives the basis for the development of the system of corrective measures in its work.

\section{Acknowledgement}

The research is executed with a financial support of the Russian humanitarian scientific fund within the project № 15-1233001 "Development and realization of a model of the prevention of tax offenses at the regional level (on the example of the Vladimir region)".

\section{References}

Efremova, T.A. (2014) Kachestvo i rezultativnost nalogovogo administrirovaniya: metodiki otsenki i ih harakteristika // Finansy i biznes. № 2. pp. 70-77.

Zolochevskaya, E.Yu. (2011) Sistema nalogovyh indikatorov v nalogovom analize // Upravlenchesky uchet. № 2. pp. 67-71.

Kartashova, G.N. (2003) K voprosu o razrabotke metodiki otsenki effektivnosti raboty nalogovyh organov // Nalogovyi vestnik. № 11. pp. 11-15.

Krylov, D.V. (2000) Ekonomicheskaya otsenka organizatsii nalogovogo administrirovaniya: author's abstract... cand. econ. sc. Izhevsk. pp. 27.

Meshkova, D.A. (2011) Nalogovyi kontrol: formy osushhestvleniya i rezultativnost // Buhgalter i zakon. № 6. pp. 10-13.

Morozov, M.S. (2007) Effektivnost kontrolnoi raboty nalogovyh organov RF // Electronic scientific nauchnoe edition «Servis v Rossii i za rubezhom». № 4. Access mode: URL: http://old.rguts.ru/electronic journal/number4/contents/economy.

Official site of the Federal tax authority of the Russian Federation - Access mode: URL: // http://www.nalog.ru

The order of the Ministry of Taxes and Tax Collection of the Russian Federation from 01.09.2003 № BG-3-06/481 « On the statement of a methodology of assessment of the control work efficiency of Ministry of Taxes and Tax Collection departments of Russia on subjects of the Russian Federation» - Access mode: URL: http://www.zakonprost.ru/content/base/part/45676

Semenova, O.Yu. \& Kiselev N.V. (2012) Analiz effektivnosti nalogovogo kontrolya // Nauchnyj vestnik KGTU. № 1. - Access mode: URL: http://vestnik.kstu.edu.ru/numbers.php?id_k=17.

Smirnova, E.E. (2008) O sovershenstvovanii kontrolnoi raboty nalogovyh organov (on materials of a poll of tax authorities workers) /I Nalogovyj vestnik. № 2. Access mode: URL: http://www.nalvest.ru/nv-articles/detail.php?ID=31341.

Chaikovskaya, N.V. (2011) Organizatsiya i metodika provedeniya nalogovogo kontrolya / Teoriya i praktika garmonizatsii informatsionnyh potokov v uchetno-nalogovoi sisteme na makro- i mikrourovne: monograph / [L.V. Popova and ot.]; edited by L.V. Popova. - Orel.: GU-UNPK. pp. 430.

Chaikovskaya, N.V. \& Smirnova, M.V. (2015) Kompleksnyi analiz deyatelnosti nalogovogo organa (on the example MI of the FTS №4 of Russia for the Vladimir region ) // Ekonomika i predprinimatelstvo. № 7. Access mode: URL: http://www.intereconom.com/ 
archive.html.

Shherbinin, A.T. (2007) Ob otsenke effektivnosti funktsionirovaniya nalogovyh organov ili nalogooblozheniya // Nalogovyi vestnik. № 1. pp. 23-27.

Kangave, J. (2005) Improving tax administration: a case study of the Uganda Revenue authority. Journal of African Law, 49, 2 (145176), 0021-8553. DOI: $10.1017 /$ S0021855305000124.

Stiglingh, M. (2014) Service quality framework for the South African Revenue Service from the perspective of the tax practitioner. Public Relations Review, 40, 2 (240-250), 0363-8111. DOI: 10.1016/j.pubrev.2013.11.014. 